\title{
PENGARUH IMPLEMENTASI KEBIJAKAN DIKLATPIM POLA BARU DAN KOMPETENSI KEPEMIMPINAN MO'ODELO TERHADAP KUALITAS PELAYANAN PUBLIK DI PEMERINTAH PROVINSI GORONTALO
}

\author{
THE EFFECT OF LEADERSHIP TRAINING PROGRAM WITH NEWEST \\ PATTERN AND MO'ODELO LEADERSHIP ON PUBLIC SERVICES QUALITY \\ IN GORONTALO PROVINCIAL GOVERNMENT
}

\author{
Irfan Ibrahim \\ Badan Pendidikan dan Pelatihan Provinsi Gorontalo \\ email: irfanibrgorontalo@gmail.com
}

\begin{abstract}
Abstrak
Tujuan penelitian ini adalah untuk menganalisis dan mengetahui pengaruh implementasi kebijakan Diklatpim IV Pola Baru terhadap kualitas pelayanan publik dimediasi oleh kompetensi kepemimpinan dengan pendekatan mo'odelo sebagai variabel intervening. Penelitian ini menggunakan jenis penelitian kuantitatif dengan metode eksplanatory survey. Teknik pengumpulan data menggunakan angket dan wawancara. Analisis data menggunakan pendekatan PLS (Partial Least Square) dengan bantuan aplikasi SmartPLS 3.1. Populasi adalah seluruh Pejabat Eselon IV yang ada di Pemerintah Provinsi Gorontalo dan ASN pada Badan Diklat Provinsi Gorontalo, jumlah populasi sebanyak 520 dengan sampel sebanyak 84 responden. Hasil penelitian menunjukkan bahwa: (1) Implementasi Kebijakan Diklatpim IV Pola Baru tidak berpengaruh langsung terhadap Kualitas Pelayanan Publik; (2) Implementasi Kebijakan Diklatpim IV Pola Baru berpengaruh tidak langsung terhadap Kualitas Pelayanan Publik di mediasi oleh Kompetensi Kepemimpinan dengan Pendekatan Mo'odelo. Rekomendasi dari penelitian ini kepada Pemerintah Provinsi Gorontalo agar melakukan program pengembangan Kompetensi Kepemimpinan dengan Pendekatan Mo'odelo sebagai kearifan lokal kepada pejabat-pejabatnya terutama dalam rangka peningkatan kualitas pelayanan publik, mengingat bahwa Diklat Kepemimpinan sendiri tidak secara langsung berpengaruh terhadap kualitas pelayanan publik. Pengaruh tersebut baru bisa terjadi bila ditunjang dengan kearifan lokal seperti Kepemimpinan Mo'odelo.
\end{abstract}

Kata Kunci: Kebijakan Diklat, Kompetensi Kepemimpinan, dan Kualitas Pelayanan Publik.

\begin{abstract}
The purpose of this study was to analyze and determine the effect of the improved leadership training program designed for lower level public service managers on the quality of public service in which the local wisdom of Mo'odelo leadership was treated as an intervening variable. This research used quantitative research with explanatory survey method. Data were collected through questionnaires and interviews. The data analyzed using PLS (Partial Least Square) technique with SmartPLS 3.1 as a software. The population consisted of lower level managers within the Gorontalo Provincial Government and ASN personnel at the Gorontalo Province Training Agency amounting to 520 people. Eighty-four sample respondents were drawn from the population. The results showed that: (1) the newly improved leadership program for lower level did not directly affect on Public Services Quality; (2) the effect of the new leadership program on Public Services quality was mediated by indigenous Leadership Competency called Mo'odelo. This study therefore recommends that Gorontalo Provincial Government should complement the leadership development program with Mo'odelo as local wisdom if main goals to improvement of public service quality, because leadership training did not
\end{abstract}


directly affect on the Public Services Quality. The effect can only occur if supported by the local wisdom such as mo'odelo leadership.

Keywords: Training Policy, Leadership Competency, and Public Services Quality.

\section{PENDAHULUAN}

Setiap organisasi publik terutama yang berhubungan langsung dengan pelayanan publik senantiasa perlu untuk meningkatkan kualitas dan kinerja pelayanan mengingat semakin hari masyarakat semakin memahami haknya akan pelayanan publik yang berkualitas dan profesional serta telah memiliki berbagai saluran komunikasi untuk menyuarakan tuntutan akan hak tersebut.

Untuk dapat memenuhi tuntutan akan kualitas pelayanan publik ini, organisasi pemerintahan membutuhkan aparatur pemerintah, terutama pejabat eselon IV yang memiliki kemampuan memimpin dan mempengaruhi serta memobilisasi bawahan dalam memberikan layanan publik yang berkualitas. Maka untuk membentuk sosok aparatur/pejabat struktural eselon IV seperti ini, perlu diimplementasikan Pendidikan dan Pelatihan Kepemimpinan (Diklatpim) IV Pola Baru yang memungkinkan peserta mampu berlatih dan menerapkan kemampuan memimpin dalam rangka peningkatan kinerja dan kualitas pelayanan organisasinya.

Selain faktor implementasi Diklatpim IV Pola Baru, upaya peningkatan kualitas pelayanan publik organisasi pemerintahan di tingkat pusat maupun daerah, dipengaruhi oleh faktor kompetensi pejabat di level lower manager yang merupakan manajer terdepan dalam pelayanan. Sejumlah kompetensi dibutuhkan dalam rangka penataan kegiatan pelayanan di unit kerja yang dipimpinnya. Salah satu kompetensi yang menjadi tuntutan dalam pelaksanaan kegiatan pelayanan publik adalah adanya kompetensi kepemimpinan berbasis kearifan lokal sebagaimana konsep yang dikemukakan oleh Setiawan dkk (2015:31) yakni konsep Kompetensi Kepemimpinan yang mengakomodir nilai-nilai budaya/kearifan lokal. Di daerah Gorontalo sendiri terdapat suatu karakteristik kepemimpinan berbasis kearifan lokal yang disebut dengan kepemimpinan mo'odelo (Botutihe, 2006:127), yang diinternalisasi sebagai sebuah kompetensi kepemimpinan pejabat struktural eselon IV sebagai upaya untuk meningkatkan kualitas pelayanan publik di Provinsi Gorontalo.

Dengan demikian peningkatan kualitas pelayanan publik sebagai masalah utama dalam penelitian ini, dibahas pada dua aspek yakni: Pertama, Implementasi Kebijakan Diklatpim IV Pola Baru, dalam hal ini kebijakan Diklatpim IV Pola Baru sebagaimana diamanahkan dalam Peraturan Kepala Lembaga Administrasi Negara Nomor 13 
Tahun 2013 dan Nomor 20 Tahun 2015 tentang Pedoman Penyelenggaraan Diklatpim IV. Sebagai bentuk kebijakan publik, implementasi Peraturan Kepala LAN ini akan menjadi sia-sia jika tidak dapat dilaksanakan dengan baik dan benar, dengan demikian efektifitas implementasi Diklatpim Pola Baru ini mutlak diperlukan sehingga Peraturan Kepala LAN ini dapat dilaksanakan secara maksimal dan dapat mencapai tujuan kebijakan itu sendiri. Oleh karena itu teori dari variabel ini diadopsi dari teori implementasi kebijakan model YK (Kadji, 2015:66) atau disebut juga model $M S N$ Approach, mengemukakan tiga pendekatan yakni: (1) Pendekatan Mentalitas; (2) Pendekatan System; dan (3) Pendekatan Networking. Dari ketiga dimensi ini kemudian diturunkan menjadi 17 indikator meliputi: saling menghargai, disiplin, integritas, keberanian bertindak, tanggung jawab, transparan, mudah dilaksanakan, kepuasan pelanggan, sistem kerja, interaksi, hubungan harmonis, kesetaraan, dukungan pimpinan, pengembangan SDM, dukungan dana, saling membutuhkan, dan saling menguntungkan.

Kedua, Kompetensi Kepemimpinan dengan Pendekatan Mo'odelo, dalam hal ini Kompetensi Kepemimpinan Pejabat Eselon IV di Pemerintah Provinsi Gorontalo sebagai bentuk kompetensi yang diperlukan dari pemimpin di era globalisasi ini yang bersinergi dengan nilai-nilai kearifan lokal. Kompetensi kepemimpinan tersebut khususnya bagi pemimpin level low manager (Pejabat Struktural Eselon IV) sebagai pejabat ujung tombak pelayanan publik diwujudkan dengan kemampuannya dalam memimpin perubahan di unit kerjanya menuju pelayanan yang lebih baik. Berdasarkan penelusuran kompetensi kepemimpinan berbasis pendekatan kearifan lokal di Daerah Gorontalo, didapati sebuah model pendekatan kompetensi kepemimpinan "Mo'odelo" sebagai prasyarat-prasyarat kepemimpinan yang ideal menurut nilai-nilai lokal di daerah Gorontalo (Botutihe dan Daulima, 2005:45). Karakteristik dari pendekatan kompetensi kepemimpinan ini sebagaimana dikemukakan oleh Botutihe (2006:129) bahwa untuk menjadi seorang Ta'uwa (gelar yang diberikan kepada pemimpin yang memenuhi persyaratan mo'odelo) semestinya memiliki 8 (delapan) prasyarat yakni: (1) memiliki dudelo (Karakter) yang baik; (2) mo'ulindhapo (cerdas merencanakan); (3) membangun dulohupa (permufakatan); (4) memelihara huyula (Mampu berkolaborasi); (5) memiliki balatayipilo (ketegaran); (6) berkarakter ponuwa (mengayomi); (7) tinepo wawu tombula'o (Menggali potensi); dan (8) serta ikilale (berinovasi). Lebih lanjut dikemukakan oleh Botutihe (2006:129) bahwa untuk memenuhi kedelapan syarat kepemimpinan mo'odelo itu memang sulit, namun demikian seseorang dapat dikatakan sebagai pemimpin mo'odelo jika dia memiliki setidaknya lima aspek dari 
delapan prasyarat kepemimpinan tersebut. Oleh karena itu peneliti menginternalisasikan nilai-nilai dari karakteristik kepemimpinan kearifan lokal mo'odelo ke dalam kompetensi operasional pejabat level eselon IV sehingga diperoleh lima karakteristik kompetensi kepemimpinan dengan pendekatan mo'odelo sebagai berikut: (1) Membangun Karakter (dudelo), (2) Kemampuan Perencanaan (mo'ulindhapo), (3) Kolaborator (huyula), (4) Inovator (ikilale), dan (5) Menggali Potensi (tinepo wawu tombula'o). Kelima karakteristik ini dipilih menjadi dimensi dari kompetensi kepemimpinan dengan pendekatan mo'odelo serta diturunkan menjadi 25 indikator meliputi: mematuhi kode etik, taat norma, memahami bawahan, mengendalikan emosi, ketaatan spiritual, mengidentifikasi masalah, memberi solusi, kejelasan program kerja, penerimaan bawahan, mengorganisasikan rencana, komunikasi, mudah dimengerti, menyatukan perbedaan, menyamakan persepsi, kerjasama tim, kekompakan tim, menciptakan ide baru, memimpin perubahan, mendorong perubahan, adaptif, mengenali potensi, memberi kesempatan, memfasilitasi potensi, dan inspirator.

Ketiga, Teori dari variabel kualitas pelayanan publik diadaptasi dari teori Parasuraman, Zeithaml, dan Berry (1988:98), dimana dalam teorinya mengemukakan lima indikator dalam menilai kualitas layanan, yang meliputi: (1) Tangibles; (2) Emphaty; (3)
Reliability; (4) Responsiveness; dan (5) Assurance. Dari kelima dimensi ini kemudian diturunkan menjadi 17 indikator sebagai berikut: ketersediaan fasilitas gedung, kebersihan fasilitas, jumlah petugas, keramahan petugas, penguasaan tugas, ketepatan waktu pelayanan, penerapan SPM, pelayanan cepat, sesuai harapan, kemampuan petugas, kesanggupan membantu, tanggap keinginan, penanganan keluhan, keamanan, SOP pengamanan, kepastian biaya, dan kemudahan dihubungi.

Peningkatan Kualitas Pelayanan Publik sebagai masalah utama yang akan dibahas melalui Implementasi Kebijakan Diklatpim IV Pola Baru dan Peningkatan Kompetensi Kepemimpinan dengan pendekatan mo'odelo, yang tentunya akan dibuktikan melalui aktivitas penelitian dengan hipotesis sebagai berikut:

1. Terdapat pengaruh signifikan Implementasi Kebijakan Diklatpim IV Pola Baru terhadap Kualitas Pelayanan Publik di Pemerintah Provinsi Gorontalo.

2. Terdapat pengaruh signifikan Implementasi Kebijakan Diklatpim IV Pola Baru terhadap Kompetensi Kepemimpinan dengan Pendekatan Mo'odelo di Pemerintah Provinsi Gorontalo.

3. Terdapat pengaruh signifikan Kompetensi Kepemimpinan dengan Pendekatan Mo'odelo terhadap Kualitas Pelayanan Publik di Pemerintah Provinsi Gorontalo. 
4. Terdapat pengaruh signifikan Implementasi Kebijakan Diklatpim IV Pola Baru terhadap Kualitas Pelayanan Publik dimediasi oleh Kompetensi Kepemimpinan dengan Pendekatan Mo'odelo di Pemerintah Provinsi Gorontalo.

\section{METODE PENELITIAN}

Pelaksanaan penelitian ini dilakukan selama tiga bulan dari bulan Juni 2018 sampai dengan bulan Agustus 2018 di lingkungan Pemerintah Provinsi Gorontalo yang meliputi 32 Organisasi Kerja Perangkat Daerah (OPD) menggunakan desain kuantitatif dengan metode eksplanatori survey, yakni metode causality research untuk menjelaskan sebab akibat yang terjadi (Kadji, 2016:72).

Mengingat kompleksitas variabel dalam penelitian ini, maka analisis data yang digunakan adalah analisis Partial Least Square (PLS) dengan bantuan software SmartPLS 3.1. Populasi dalam penelitian ini merupakan keseluruhan ASN pada Badan Diklat Provinsi Gorontalo dan Pejabat Struktural Eselon IV yang tersebar di 32 OPD dengan keseluruhan anggota populasi berjumlah 520 orang. Adapun sampel dalam penelitian ini sebanyak 84 responden yang penarikan sampelnya berdasarkan rumus Slovin (Mulyadi, 2016:115), yakni: $\quad \mathrm{n}=\frac{\mathrm{N}}{1+\mathrm{Ne}^{2}}, \quad$ dan memperhatikan responden memiliki strata berdasarkan Golongan yakni Golongan IV sebanyak 60 orang, Golongan III sebanyak 447 orang dan Golongan II sebanyak 13 orang, maka anggota sampel dari tiap strata ditentukan berdasarkan proportional stratified random sampling menggunakan rumus $n_{i}=\frac{N_{1}}{N} \times n$, sebagaimana dikemukakan oleh Harun Al Rasyid (Mulyadi, 2016:116), sehingga anggota sampel dalam setiap strata adalah sebagai berikut: Golongan IV sebanyak 10 responden, Golongan III sebanyak 72 responden, dan Golongan II sebanyak 2 responden.

Teknik pengumpulan data yang digunakan disesuaikan jenis dan sumber data yang diperlukan. Data primer diperoleh melalui teknik kuesioner, wawancara dan observasi, serta data sekunder diperoleh melalui studi dokumentasi dan kepustakaan. Kegiatan pengumpulan data penelitian dengan menggunakan instrumen berupa angket yang disusun secara terstruktur. Angket terdiri dari beberapa butir pertanyaan disertai alternatif jawaban, sehingga responden dapat memilih jawaban sesuai dengan keadaan yang sebenarnya. Adapun tingkat pengukuran variabel adalah ordinal dan kategori jawaban tertutup yang meliputi lima (5) kategori jawaban dengan berpedoman pada skala perbedaan semantik yang menunjukkan adanya gradasi dari nilai yang sangat ideal hingga nilai yang sangat tidak ideal, yakni dari angka/bobot $5,4,3,2$, dan 1 .

Selanjutnya data dianalisis dengan menggunakan Software SmartPLS 3.1 berpedoman pada tujuh langkah analisis 
berdasarkan Ghozali dan Latan (2015:47-54) yakni: membentuk model struktural; membentuk model pengukuran; membuat diagram jalur; estimasi model; bootstrapping; evaluasi model; dan interpretasi model.

\section{HASIL PENELITIAN}

\section{Hasil Uji Validitas dan Reliabilitas}

\section{Kesesuaian Model Pengukuran.}

Hasil uji kesesuaian model pengukuran untuk variabel Implementasi Kebijakan Diklatpim IV Pola baru dapat dilihat pada tabel berikut:

\section{Tabel 1. Uji Validitas Indikator Variabel Implementasi Diklatpim IV Pola Baru.}

\begin{tabular}{|c|c|c|c|}
\hline \multirow{2}{*}{ No } & \multirow{2}{*}{ Indikator } & \multicolumn{2}{|c|}{$\begin{array}{c}\text { Validitas } \\
\text { Convergent }\end{array}$} \\
\hline & & $\begin{array}{l}\text { Loading } \\
\text { Factor }\end{array}$ & Ket \\
\hline 1. & $\mathrm{X}_{1.1}$ (Saling menghargai) & 0,621 & Valid \\
\hline 2. & $\mathrm{X}_{1.2}($ Disiplin $)$ & 0,692 & Valid \\
\hline 3. & $\mathrm{X}_{1.3}$ (Integritas) & 0,777 & Valid \\
\hline 4. & $\begin{array}{c}\mathrm{X}_{1.4}(\text { Keberanian } \\
\text { bertindak })\end{array}$ & 0,666 & Valid \\
\hline 5. & $\mathrm{X}_{1.5}$ (Tanggung jawab) & 0,782 & Valid \\
\hline 6. & $\mathrm{X}_{2.1}$ (Transparan) & 0,584 & Valid \\
\hline 7. & $\mathrm{X}_{2.2}$ (Mudah dilaksanakan) & 0,674 & Valid \\
\hline 8. & $\mathrm{X}_{2.3}$ (Kepuasan pelanggan) & 0,645 & Valid \\
\hline 9. & $\mathrm{X}_{2.4}($ Sistem kerja $)$ & 0,655 & Valid \\
\hline 10. & $\begin{array}{l}\mathrm{X}_{2.5}(\text { Interaksi } \\
\text { stakeholders })\end{array}$ & 0,686 & Valid \\
\hline 11. & $\mathrm{X}_{2.6}$ (Hubungan harmonis) & 0,647 & Valid \\
\hline 12. & $\mathrm{X}_{3.1}($ Kesetaraan $)$ & 0,523 & Valid \\
\hline 13. & $\mathrm{X}_{3.2}$ (Dukungan pimpinan) & 0,682 & Valid \\
\hline 14. & $\begin{array}{l}\mathrm{X}_{3.3} \text { (Pengembangan } \\
\text { SDM })\end{array}$ & 0,729 & Valid \\
\hline 15. & $\mathrm{X}_{3.4}$ (Dukungan dana) & 0,469 & $\begin{array}{l}\text { Tidak } \\
\text { Valid }\end{array}$ \\
\hline 16. & $\begin{array}{l}\mathrm{X}_{3.5} \text { (Saling } \\
\text { membutuhkan })\end{array}$ & 0,815 & Valid \\
\hline 17. & $\begin{array}{l}\mathrm{X}_{3.6} \text { (Saling } \\
\text { menguntungkan) }\end{array}$ & 0,587 & Valid \\
\hline
\end{tabular}

Tabel di atas, menunjukkan bahwa dari 17 indikator terdapat satu indikator $\left(\mathrm{X}_{3.4}\right)$ yang nilai loading factor-nya di bawah 0,5 . Oleh karena itu indikator tersebut dikeluarkan dari analisis karena tidak memenuhi nilai convergent validity.

Hasil uji kesesuaian model pengukuran untuk variabel kedua, yakni Variabel Kompetensi Kepemimpinan dengan Pendekatan Mo'odelo dapat dilihat sebagaimana tabel berikut:

Tabel 2. Uji Validitas Indikator Variabel Kompetensi Kepemimpinan dengan Pendekatan Mo’odelo.

\begin{tabular}{|c|c|c|c|}
\hline \multirow{2}{*}{$\begin{array}{l}\mathrm{N} \\
\mathrm{O}\end{array}$} & \multirow{2}{*}{ Indikator } & \multicolumn{2}{|c|}{$\begin{array}{c}\text { Validitas } \\
\text { Convergent }\end{array}$} \\
\hline & & $\begin{array}{l}\text { Loading } \\
\text { Factor }\end{array}$ & Ket \\
\hline 1 & $\begin{array}{l}\mathrm{Y}_{1.1 .1} \text { (Mematuhi kode } \\
\text { etik) }\end{array}$ & 0,642 & Valid \\
\hline 2 & $\mathrm{Y}_{1.1 .2}($ Taat norma $)$ & 0,661 & Valid \\
\hline 3 & $\begin{array}{c}\mathrm{Y}_{1.1 .3} \text { (Memahami } \\
\text { bawahan) }\end{array}$ & 0,833 & Valid \\
\hline 4 & $\begin{array}{c}\mathrm{Y}_{1.1 .4} \text { (Mengendalikan } \\
\text { emosi) }\end{array}$ & 0,742 & Valid \\
\hline 5 & $\mathrm{Y}_{1.1 .5}($ Ketaatan spiritual $)$ & 0,361 & $\begin{array}{l}\text { Tidak } \\
\text { Valid }\end{array}$ \\
\hline 6 & $\begin{array}{l}\mathrm{Y}_{1.2 .1} \text { (Mengidentifikasi } \\
\text { masalah) }\end{array}$ & 0,689 & Valid \\
\hline 7 & $\mathrm{Y}_{1.2 .2}($ Memberi solusi) & 0,654 & Valid \\
\hline 8 & $\begin{array}{l}\mathrm{Y}_{1.2 .3} \text { (Kejelasan Program } \\
\text { kerja) }\end{array}$ & 0,789 & Valid \\
\hline 9 & $\begin{array}{c}\mathrm{Y}_{1.2 .4}\left(\begin{array}{c}\text { Penerimaan } \\
\text { bawahan })\end{array}\right.\end{array}$ & 0,373 & $\begin{array}{l}\text { Tidak } \\
\text { Valid }\end{array}$ \\
\hline 10 & $\begin{array}{c}\mathrm{Y}_{1.2 .5} \text { (Mengorganisasikan } \\
\text { rencana) }\end{array}$ & 0,637 & Valid \\
\hline 11 & $\begin{array}{l}\mathrm{Y}_{1.3 .1}(\text { Strategi } \\
\text { Komunikasi }) \\
\end{array}$ & 0,712 & Valid \\
\hline 12 & $\mathrm{Y}_{1.3 .2}$ (Mudah dimengerti) & 0,821 & Valid \\
\hline & $\begin{array}{c}\mathrm{Y}_{1.3 .3} \text { (Menyatukan } \\
\text { perbedaan })\end{array}$ & 0,868 & Valid \\
\hline 14 & $\begin{array}{l}\mathrm{Y}_{1.3 .4} \text { (Menyamakan } \\
\text { persepsi) }\end{array}$ & 0,737 & Valid \\
\hline 15 & $\mathrm{Y}_{1.3 .5}($ Kerjasama Tim $)$ & 0,719 & Valid \\
\hline 16 & $\mathrm{Y}_{1.3 .6}($ Kekompakan Tim) & 0,774 & Valid \\
\hline 17 & $\begin{array}{l}\mathrm{Y}_{1.4 .1} \text { (Menciptakan ide } \\
\text { baru) }\end{array}$ & 0,586 & Valid \\
\hline 18 & $\mathrm{Y}_{1.4 .2}$ (Cara berpikir baru) & 0,711 & Valid \\
\hline
\end{tabular}




\begin{tabular}{|c|c|c|c|}
\hline \multirow{2}{*}{$\begin{array}{c}\mathrm{N} \\
\mathrm{O}\end{array}$} & \multirow{2}{*}{ Indikator } & \multicolumn{2}{|c|}{$\begin{array}{c}\text { Validitas } \\
\text { Convergent }\end{array}$} \\
\hline & & $\begin{array}{l}\text { Loading } \\
\text { Factor }\end{array}$ & Ket \\
\hline 19 & $\begin{array}{c}\mathrm{Y}_{1.4 .3}(\text { Memimpin } \\
\text { perubahan })\end{array}$ & 0,856 & Valid \\
\hline 20 & $\begin{array}{c}\mathrm{Y}_{1.4 .4} \text { (Mendorong } \\
\text { perubahan) }\end{array}$ & 0,811 & Valid \\
\hline 21 & $\mathrm{Y}_{1.4 .5}$ (Adaptif) & 0,690 & Valid \\
\hline 22 & $\mathrm{Y}_{1.5 .1}$ (Mengenali Potensi) & 0,568 & Valid \\
\hline 23 & $\begin{array}{l}\mathrm{Y}_{1.5 .2}(\text { Memberi } \\
\text { kesempatan })\end{array}$ & 0,812 & Valid \\
\hline 24 & $\begin{array}{c}\mathrm{Y}_{1.5 .3} \text { (Memfasilitasi } \\
\text { Potensi) }\end{array}$ & 0,813 & Valid \\
\hline 25 & $\mathrm{Y}_{1.5 .4}$ (Inspirator) & 0,782 & Valid \\
\hline
\end{tabular}

Sumber: Data Olahan

Tabel di atas, menunjukkan terdapat dua indikator yang nilai loading factor-nya di bawah 0,5 yakni indikator $\mathrm{Y}_{1.1 .5}$ dan indikator $\mathrm{Y}_{1.2 .4}$. Oleh karena itu kedua indikator tersebut harus dikeluarkan dari model karena belum memenuhi convergent validity yang dipersyaratkan untuk uji validitas.

Hasil uji kesesuaian model pengukuran untuk variabel ketiga, yakni Variabel Kualitas Pelayanan Publik dapat dilihat sebagaimana tabel berikut:

\section{Tabel 3. Uji Validitas Indikator Variabel Kualitas Pelayanan Publik.}

\begin{tabular}{|c|c|c|c|}
\hline \multirow[b]{2}{*}{ No } & \multirow[b]{2}{*}{ Indikator } & \multicolumn{2}{|c|}{$\begin{array}{c}\text { Validitas } \\
\text { Convergent }\end{array}$} \\
\hline & & $\begin{array}{c}\text { Loadin } \\
g \\
\text { Factor }\end{array}$ & Ket \\
\hline 1 & $\mathrm{Y}_{2.1 .1}$ (Fasilitas gedung $)$ & 0,850 & Valid \\
\hline 2 & $\mathrm{Y}_{2.1 .2}$ (Kebersihan fasilitas) & 0,896 & Valid \\
\hline 3 & $\mathrm{Y}_{2.1 .3}$ (Jumlah Petugas) & 0,657 & Valid \\
\hline 4 & $\mathrm{Y}_{\text {2.2.1 }}$ (Keramahan Petugas) & 0,667 & Valid \\
\hline 5 & $\mathrm{Y}_{\text {2.2.2 }}$ (Penguasaan tugas) & 0,879 & Valid \\
\hline 6 & $\begin{array}{l}\mathrm{Y}_{2.2 .3} \text { (Ketepatan waktu } \\
\text { pelayanan) }\end{array}$ & 0,838 & Valid \\
\hline 7 & $\mathrm{Y}_{\text {2.2.4 }}($ Penerapan SPM $)$ & 0,819 & Valid \\
\hline 8 & $\mathrm{Y}_{2.3 .1}$ (Pelayanan cepat) & 0,710 & Valid \\
\hline 9 & $\mathrm{Y}_{2.3 .2}($ Sesuai harapan $)$ & 0,816 & Valid \\
\hline 10 & $\mathrm{Y}_{2.3 .3}$ (Kemampuan petugas) & 0,777 & Valid \\
\hline 11 & $\begin{array}{c}\mathrm{Y}_{2.4 .1} \text { (Kesanggupan } \\
\text { membantu) }\end{array}$ & 0,888 & Valid \\
\hline
\end{tabular}

\begin{tabular}{|c|c|c|c|}
\hline \multirow[b]{2}{*}{ No } & \multirow[b]{2}{*}{ Indikator } & \multicolumn{2}{|c|}{$\begin{array}{c}\text { Validitas } \\
\text { Convergent }\end{array}$} \\
\hline & & $\begin{array}{c}\text { Loadin } \\
g \\
\text { Factor }\end{array}$ & Ket \\
\hline 12 & $\mathrm{Y}_{\text {2.4.2 }}$ (Tanggap keinginan) & 0,858 & Valid \\
\hline 13 & $\mathrm{Y}_{2.4 .3}$ (Penanganan keluhan) & 0,768 & Valid \\
\hline 14 & $\mathrm{Y}_{2.5 .1}$ (Petugas keamanan) & 0,859 & Valid \\
\hline 15 & $\mathrm{Y}_{2.5 .2}$ (SOP Pengamanan) & 0,903 & Valid \\
\hline 16 & $\mathrm{Y}_{2.5 .3}($ Kepastian biaya $)$ & 0,721 & Valid \\
\hline 17 & $\begin{array}{c}\mathrm{Y}_{2.5 .4} \text { (Kemudahan } \\
\text { dihubungi) }\end{array}$ & 0,908 & Valid \\
\hline
\end{tabular}

Sumber: Data Olahan

Berdasarkan tabel di atas, menunjukkan bahwa seluruh indikator dari Variabel Kualitas Pelayanan Publik dapat dikatakan valid karena berada di atas 0,5 .

Setelah dilakukan perbaikan dengan mengeluarkan indikator yang tidak valid, selanjutnya dilakukan uji validitas dan reliabilitas model dari masing-masing variabel dengan hasil nilai Cross Loading, Cronbach's Alpha, dan Composite Reliability dari masingmasing variabel lebih dari 0,6 sehingga berdasarkan hasil uji ini dapat dikatakan bahwa model dari ketiga variabel telah memenuhi persyaratan uji validitas dan reliabilitas model.

\section{Pengujian Hipotesis}

Dalam pengujian hipotesis, hasil evaluasi jalur model dari masing-masing jalur pengaruh dapat dilihat pada tabel berikut:

Tabel 4. Hasil Pengujian Hipotesis.

\begin{tabular}{|c|c|c|c|c|c|}
\hline $\begin{array}{l}\mathrm{N} \\
\mathrm{o}\end{array}$ & Jalur Pengaruh $(\rightarrow)$ & $\begin{array}{l}\text { Nilai } \\
\text { Koefisi } \\
\text { en }\end{array}$ & $\begin{array}{c}\mathrm{T} \\
\text { Statisti } \\
\mathrm{c}\end{array}$ & $\begin{array}{c}\text { P- } \\
\text { Value }\end{array}$ & $\begin{array}{c}\text { Kesimp } \\
\text { ulan }\end{array}$ \\
\hline 1 & $\begin{array}{l}\text { Implementasi } \\
\text { Kebijakan } \\
\text { Diklatpim IV Pola } \\
\text { Baru } \rightarrow \text { Kualitas } \\
\text { Pelayanan Publik. } \\
{\left[(\xi) \rightarrow\left(\mathbf{n}_{2}\right)\right]}\end{array}$ & 0,079 & 0,611 & 0,541 & $\begin{array}{l}\text { Tidak } \\
\text { Signifik } \\
\text { an }\end{array}$ \\
\hline 2 & $\begin{array}{l}\text { Implementasi } \\
\text { Kebijakan } \\
\text { Diklatpim IV Pola }\end{array}$ & 0,758 & 13,691 & 0,000 & $\begin{array}{c}\text { Signifik } \\
\text { an }\end{array}$ \\
\hline
\end{tabular}




\begin{tabular}{|c|c|c|c|c|c|}
\hline $\begin{array}{l}N \\
0\end{array}$ & Jalur Pengaruh $(\rightarrow)$ & $\begin{array}{l}\text { Nilai } \\
\text { Koefisi } \\
\text { en }\end{array}$ & $\begin{array}{c}\mathrm{T} \\
\text { Statisti } \\
\mathrm{c}\end{array}$ & $\begin{array}{c}\text { P- } \\
\text { Value }\end{array}$ & $\begin{array}{c}\text { Kesimp } \\
\text { ulan }\end{array}$ \\
\hline & $\begin{array}{l}\text { Baru } \rightarrow \\
\text { Kompetensi } \\
\text { Kepemimpinan } \\
\text { dengan Pendekatan } \\
\text { Mo'odelo } \\
{\left[(\xi) \rightarrow\left(\mathbf{\eta}_{1}\right)\right]}\end{array}$ & & & & \\
\hline 3 & $\begin{array}{l}\text { Kompetensi } \\
\text { Kepemimpinan } \\
\text { dengan Pendekatan } \\
\text { Mo'odelo } \\
\rightarrow \text { Kualitas } \\
\text { Pelayanan Publik } \\
{\left[\left(\mathbf{I}_{1}\right) \rightarrow\left(\mathbf{I}_{2}\right)\right]}\end{array}$ & 0,604 & 5,062 & 0,000 & $\begin{array}{c}\text { Signifik } \\
\text { an }\end{array}$ \\
\hline 4 & $\begin{array}{l}\text { Implementasi } \\
\text { Kebijakan } \\
\text { Diklatpim IV Pola } \\
\text { Baru } \rightarrow \text { Kompetensi } \\
\text { Kepemimpinan } \\
\text { dengan Pendekatan } \\
\text { Mo'odelo } \\
\rightarrow \text { Kualitas } \\
\text { Pelayanan Publik } \\
{\left[(\xi) \rightarrow\left(\mathbf{\eta}_{1}\right) \rightarrow\left(\mathbf{\eta}_{2}\right)\right] \text {. }}\end{array}$ & 0,681 & 9,377 & 0,000 & $\begin{array}{c}\text { Signifik } \\
\text { an }\end{array}$ \\
\hline
\end{tabular}

Dari tabel di atas, terlihat bahwa uji hipotesis yang pertama yakni pengaruh Implementasi Kebijakan Diklatpim IV Pola Baru terhadap Kualitas Pelayanan Publik tidak signifikan pada 5\% karena nilai T-Statistic di bawah nilai $t$ table 1,96 . Begitu pula dengan nilai P-Value sebesar 0,541 berada di atas nilai signifikansi P-Value $<0,05$ dan nilai koefisien pengaruhnya hanya sebesar $7,9 \%$. Oleh karena P-Value > 0,05 maka dengan demikian untuk uji hipotesis ini didapatkan kesimpulan bahwa $\mathrm{H}_{0}$ diterima, $\mathrm{H}_{1}$ di tolak atau dengan kata lain tidak terdapat pengaruh yang signifikan Implementasi Kebijakan Diklatpim IV Pola Baru terhadap Kualitas Pelayanan Publik di Pemerintah Provinsi Gorontalo.

Hasil uji hipotesis kedua, yakni pengaruh Implementasi Kebijakan Diklatpim IV Pola Baru terhadap Kompetensi Kepemimpinan dengan Pendekatan Mo’odelo, signifikan pada
5\% karena nilai T-Statistic dari second order tersebut sebesar 13,691 memiliki nilai di atas nilai t table 1,96 . Begitu pula dengan nilai $\mathrm{P}$ Value sebesar 0,000 berada pada nilai signifikansi P-Value $<0,05$ dan nilai koefisien pengaruhnya sebesar $75,8 \%$. Oleh karena itu untuk uji hipotesis ini didapatkan kesimpulan bahwa $\mathrm{H}_{1}$ diterima, $\mathrm{H}_{0}$ di tolak atau dengan kata lain terdapat pengaruh yang signifikan Implementasi Kebijakan Diklatpim IV Pola Baru terhadap Kompetensi Kepemimpinan dengan Pendekatan Mo'odelo di Pemerintah Provinsi Gorontalo.

Hasil uji hipotesis ketiga, yakni pengaruh Kompetensi Kepemimpinan dengan Pendekatan Mo'odelo terhadap Kualitas Pelayanan Publik signifikan pada 5\% karena nilai T-Statistic sebesar 5,062 memiliki nilai di atas nilai t table 1,96. Begitu pula dengan nilai $P$-Value sebesar 0,000 berada pada nilai signifikansi $P$-Value $<0,05$ dan nilai koefisien pengaruhnya sebesar $60,4 \%$. Dengan demikian untuk uji hipotesis didapatkan kesimpulan bahwa $\mathrm{H}_{1}$ diterima, $\mathrm{H}_{0}$ di tolak atau dengan kata lain terdapat pengaruh yang signifikan Kompetensi Kepemimpinan dengan Pendekatan Mo'odelo terhadap Kualitas Pelayanan Publik di Pemerintah Provinsi Gorontalo.

Hasil uji hipotesis keempat, yakni pengaruh Implementasi Kebijakan Diklatpim IV Pola Baru terhadap Kualitas Pelayanan Publik dimediasi oleh Kompetensi 
Kepemimpinan dengan Pendekatan Mo’odelo, dibentuk oleh dua jalur hubungan variabel yakni jalur Implementasi Kebijakan Diklatpim IV Pola Baru ke Kompetensi Kepemimpinan dengan Pendekatan Mo'odelo sebagai jalur hubungan pertama dan jalur Kompetensi Kepemimpinan dengan Pendekatan Mo'odelo ke Kualitas Pelayanan Publik sebagai jalur hubungan kedua. Kedua jalur hubungan pengaruh ini signifikan pada 5\% karena nilai $T$ Statistic berada di atas nilai t table 1,96. Begitu pula dengan nilai $P$-Value berada pada taraf signifikansi $P$-Value $<0,05$, maka didapatkan nilai uji pengaruh Implementasi Kebijakan Diklatpim IV Pola Baru terhadap Kualitas Pelayanan Publik dimediasi oleh Kompetensi Kepemimpinan dengan Pendekatan Mo'odelo dengan nilai T-Statistic sebesar 9,377 signifikan pada $5 \%$ karena berada di atas nilai $\mathrm{t}$ table 1,96. Begitu pula dengan nilai P-Value sebesar 0,000 berada pada taraf signifikansi $P$ Value $<0,05$ dan nilai koefisien pengaruhnya sebesar $68,1 \%$.

Oleh karena $P$-Value $<0,05$ maka dengan demikian untuk uji hipotesis didapatkan kesimpulan bahwa $\mathrm{H}_{1}$ diterima, $\mathrm{H}_{0}$ di tolak atau dengan kata lain terdapat pengaruh yang signifikan Implementasi Kebijakan Diklatpim IV Pola Baru terhadap Kualitas Pelayanan Publik dimediasi oleh Kompetensi Kepemimpinan dengan Pendekatan Mo'odelo di Pemerintah Provinsi Gorontalo.

\section{PEMBAHASAN}

\section{a. Pengaruh Implementasi Kebijakan Diklatpim IV Pola Baru Terhadap Kualitas Pelayanan Publik di Pemerintah Provinsi Gorontalo.}

Tidak signifikannya pengaruh Implementasi Kebijakan Diklatpim IV Pola Baru menunjukkan bahwa Implementasi Kebijakan Diklatpim IV Pola Baru belum berkontribusi secara signifikan dalam peningkatan Kualitas Pelayanan Publik dan memiliki koefisien sangat rendah yakni hanya sebesar 7,9\%. Hasil ini berbanding terbalik dengan hasil penelitian Basir (2016), yang menunjukkan bahwa Pendidikan dan Pelatihan Pegawai memiliki pengaruh yang signifikan terhadap kualitas pelayanan publik dengan koefisien pengaruh sebesar 52\%. Demikian pula dengan hasil penelitian Muhadi (2017) bahwa Pendidikan dan Pelatihan berpengaruh signifikan sebesar $52,7 \%$ terhadap kualitas pelayanan. Ketidak konsistenan hasil penelitian ini dengan hasil penelitian sebelumnya menunjukkan bahwa penerapan model $M S N$ Approach belum sepenuhnya diimplementasikan dengan baik oleh Implementor kebijakan (Ibrahim, 2018), baik pendekatan mentalitas, sistem, maupun networking yang terbukti dengan hasil uji pengaruh terhadap kualitas pelayanan publik yang tidak signifikan. Hal ini diperkuat pula oleh hasil wawancara, menunjukkan bahwa terdapat relevansi antara hasil uji yang tidak 
signifikan dengan belum sepenuhnya diimplementasikannya model MSN-Approach oleh Badan Diklat Provinsi Gorontalo sebagai implementor kebijakan. Kondisi ini tidak lepas dari masih rendahnya komitmen dan motivasi dari implementor di Badan Diklat Provinsi Gorontalo, baik itu unsur manajemen diklat, widyaiswara, maupun staf pelaksananya.

Kurangnya komitmen dan motivasi aparatur di atas, ternyata sejalan dengan hasil analisis deskriptif jawaban responden atas angket penelitian yang item pertanyaan memiliki nilai rendah, dimana unsur implementor kebijakan Diklatpim IV Pola Baru dinilai responden masih kurang memiliki komitmen terhadap penyelesaian tugasnya. Hal ini berpengaruh kepada sikap dan perilaku implementor yang cenderung bersikap pasif dalam proses implementasi kebijakan Diklatpim IV Pola Baru. Upaya implementor hanya sekedar untuk memenuhi ketentuanketentuan dalam peraturan saja serta tidak berorientasi pada proses, akibatnya berdampak pada kurang optimalnya implementasi kebijakan Diklatpim IV Pola Baru dalam rangka peningkatan kualitas pelayanan publik (Ibrahim, 2018).

Aspek ini sebagaimana ditegaskan oleh Edward III (1980:148) bahwa jika sikap yang dimiliki oleh implementor kebijakan rendah, seperti komitmen, kejujuran, komunikatif, dan sifat demokratis, maka proses implementasinya menjadi tidak efektif dan efisien. Demikian pula dengan Wahab (2016), menjelaskan bahwa watak dan karakteristik yang dimiliki oleh implementor, seperti komitmen, kejujuran, dan sifat demokratis sangat menentukan optimalisasi dan efektifitas implementasi kebijakan.

Diihat dari aspek motivasi, tidak maksimalnya implementasi kebijakan Diklatpim IV Pola Baru di atas, dapat dijelaskan sebagaimana pendapat Hasibuan (2003:141) bahwa motivasi berperan penting dalam mendorong dan menggerakkan potensi agar bekerja mencapai tujuan yang ditentukan, dimana jika dorongan keinginan bekerja ini rendah maka tujuan yang telah ditetapkan tidak akan tercapai. Oleh karena itu motivasi diperlukan dalam merangsang gairah berkerja setiap aparatur terutama aparatur di Badan Diklat Provinsi Gorontalo guna efektifitas implementasi kebijakan Diklatpim IV Pola Baru.

Oleh karena itu, peningkatan komitmen dan motivasi aparatur ini menjadi perlu dilakukan mengingat pelaksanaan Diklatpim IV Pola Baru tidak akan efektif jika tidak didukung dengan komitmen dan motivasi dari semua pihak dalam lingkungan kebijakan tanpa terkecuali. Hal ini sebagaimana dikemukakan oleh Weimer dan Vining (1999:396) bahwa terdapat tiga kelompok besar yang dapat mempengaruhi keberhasilan implementasi suatu program, yakni: (1) Logika kebijakan; (2) Lingkungan tempat kebijakan dioperasikan; 
dan (3) Kemampuan, motivasi, dan komitmen implementor kebijakan. Sejalan dengan pendapat Weimer dan Vinning di atas, Conner (1992:146)

$$
\text { mengemukakan }
$$

bahwa

keberhasilan pencapaian tujuan berakar pada komitmen, karena pada kenyataannya kebanyakan kegagalan pencapaian tujuan dapat dilacak kembali pada kurangnya komitmen.

\section{b. Pengaruh Implementasi Kebijakan Diklatpim IV Pola Baru Terhadap Kompetensi Kepemimpinan dengan Pendekatan Mo'odelo.}

Hasil uji hipotesis pengaruh Implementasi Kebijakan Diklatpim IV Pola Baru terhadap Kompetensi Kepemimpinan dengan Pendekatan Mo'odelo menunjukkan bahwa Implementasi Kebijakan Diklatpim IV Pola Baru berpengaruh positif secara signifikan terhadap Kompetensi Kepemimpinan dengan Pendekatan Mo'odelo.

Hasil penelitian ini konsisten dengan hasil penelitian Astra, Mandey dan Londa (2016) tentang Pengaruh Diklat Struktural terhadap Kompetensi Kepemimpinan ASN, dengan hasil bahwa Diklat Struktural berpengaruh signifikan dan berkorelasi positif terhadap Kompetensi Kepemimpinan ASN dengan korelasi determinasi sebesar $74 \%$. Begitu pula dengan hasil penelitian Koton (2016) tentang Pengaruh Pendidikan dan Pelatihan Kepemimpinan Pola Baru terhadap Kompetensi Manajerial Pejabat Struktural yang menunjukkan adanya pengaruh signifikan dengan koefisien determinasi sebesar $68,2 \%$. Hasil konsisten lainnya juga dinyatakan oleh Punu, Rompas dan Tampongangoy (2014) yang meneliti tentang Pengaruh Pendidikan dan Pelatihan terhadap Kompetensi Aparatur, mendapatkan hasil bahwa Pendidikan dan Pelatihan (Diklat) berpengaruh dan berkorelasi positif dan signifikan terhadap Kompetensi Kerja Aparatur dengan koefisien pengaruh sebesar $99,8 \%$.

Signifikannya pengaruh implementasi kebijakan Diklatpim IV Pola Baru terhadap kompetensi kepemimpinan dengan pendekatan mo'odelo ini disebabkan oleh tingginya tingkat relevansi antara kurikulum Diklatpim IV Pola Baru dengan kebutuhan peserta dan stakeholder's (Ibrahim, 2018), yang dibuktikan oleh hasil uji pengaruh implementasi kebijakan Diklatpim IV Pola Baru terhadap Kompetensi Kepemimpinan dengan pendekatan mo'odelo yang signifikan. Hal ini dikuatkan oleh hasil wawancara yang menegaskan adanya penerapan kurikulum diklat pola baru tahun 2013 yang telah disempurnakan pada tahun 2015 sebagai pedoman dalam mengimplementasikan kebijakan Diklatpim IV Pola Baru relevan dengan kebutuhan peserta diklat dan stakeholders lainya, di mana core kompetensinya bermuara pada peningkatan kemampuan adaptive leadership peserta diklat serta lebih aplikatif dibanding dengan kebijakan Diklatpim sebelumnya. Hal ini sebagaimana pendapat Syukur (2015:1) bahwa 
dalam rangka meningkatkan kompetensi kepemimpinan, kurikulum Diklatpim IV Pola Baru mengadopsi pemikiran Heifetz, Grashow dan Linsky (2009) tentang adaptive leadership, dimana kurikulum ini menekankan pada kemampuan beradaptasi terhadap nilai-nilai perubahan, memiliki enam agenda kurikulum pembelajaran yang salah satunya adalah agenda proyek perubahan sebagai implementasi langsung praktek kepemimpinan peserta di lapangan.

\section{c. Pengaruh Kompetensi Kepemimpinan}

dengan Pendekatan Mo'odelo Terhadap Kualitas Pelayanan Publik.

Hasil uji hipotesis dari Pengaruh Kompetensi Kepemimpinan dengan Pendekatan Mo'odelo terhadap Kualitas Pelayanan Publik menunjukkan bahwa Kompetensi Kepemimpinan dengan Pendekatan Mo'odelo berpengaruh signifikan terhadap kualitas pelayanan publik. Signifikannya pengaruh Kompetensi Kepemimpinan dengan Pendekatan Mo'odelo terhadap Kualitas Pelayanan Publik ini sejalan dengan hasil penelitian yang dilakukan oleh Setiawan dkk (2015), yang melakukan penelitian tentang Pengaruh Kepemimpinan Pelayan terhadap Kinerja Pelayanan Publik PNS di Kota Bekasi bahwa terdapat pengaruh signifikan dari Kepemimpinan Pelayan terhadap Kinerja Pelayanan Publik PNS di Kota Bekasi dengan koefisien determinasi Kepemimpinan Pelayanan terhadap Kinerja
Pelayanan Publik sebesar 43,6\%. Hasil penelitian ini juga konsisten dengan penelitian Pranata (2015), menunjukkan bahwa Kompetensi Aparatur berpengaruh signifikan terhadap Kualitas Pelayanan Publik dengan koefisien determinasi sebesar 77,5\%. Demikian pula konsisten dengan penelitian oleh Setyawan dan Bagus (2014), bahwa Kualitas Kepemimpinan berpengaruh signifikan terhadap Pelayanan Publik dengan koefisien determinasi sebesar 52,3\%.

Konsistensi hasil penelitian ini dengan penelitian-penelitian sebelumnya menguatkan pendapat beberapa ahli seperti pendapat Rondinelli (1998); Morgan dan Piercy (1998), bahwa dalam rangka peningkatan kualitas pelayanan publik, salah satu faktor utama yang mempengaruhinya adalah faktor kepemimpinan. Hal yang sama sebagaimana yang dikemukakan oleh Worsfold (1999:278), bahwa terdapat hubungan kausalitas yang kuat antara kompetensi dan komitmen pegawai dalam kegiatan pelayanan pelanggan.

Signifikannya pengaruh kompetensi kepemimpinan dengan pendekatan mo'odelo terhadap kualitas pelayanan publik disebabkan oleh adanya faktor kemampuan berinovasi dalam pelayanan sehingga berdampak pada meningkatnya kualitas pelayanan publik (Ibrahim, 2018). Hal ini terbukti dari hasil uji pengaruh kompetensi kepemimpinan dengan pendekatan mo'odelo yang signifikan terhadap kualitas pelayanan publik serta dikuatkan oleh 
hasil wawancara peneliti yang mempertegas bahwa hasil uji pengaruh kompetensi kepemimpinan dengan pendekatan mo'odelo yang signifikan terhadap kualitas pelayanan publik tidak lain disebabkan oleh adanya kemampuan berinovasi pejabat eselon IV sebagai wujud dari kompetensi kepemimpinan dengan pendekatan mo'odelo. Hasil ini disamping menunjukkan peran inovasi dalam peningkatan kualitas pelayanan publik di lingkungan Pemerintah Provinsi Gorontalo, juga mempertegas pendapat Robbins (2002:248) yang mengemukakan tujuh karakteristik budaya organisasi yang dibutuhkan untuk peningkatan kinerja dan layanan organisasi, yang salah satunya adalah inovasi.

Temuan hasil penelitian ini lebih mempertegas pendapat beberapa ahli, seperti pendapat Widodo (2002:56), bahwa untuk meningkatkan pelayanan publik diperlukan kemampuan dan kompetensi kepemimpinan aparatur pemerintah agar pelayanan masyarakat dapat dipertanggungjawabkan sesuai dengan harapan publik. Begitu pula dengan pendapat Greenleaf (1977), yang mengemukakan konsep Servant Leadership (kepemimpinan melayani) guna meningkatkan kualitas pelayanan publik, yakni konsep kompetensi kepemimpinan dalam mengatur, mengelola dan melayani masyarakat dengan lebih memprioritaskan pelayanan (pemenuhan kebutuhan) orang lain di atas kebutuhan pribadi/golongan.

\section{d. Pengaruh Implementasi Kebijakan \\ Diklatpim IV Pola Baru Terhadap Kualitas Pelayanan Publik dimediasi Kompetensi Kepemimpinan dengan Pendekatan Mo'odelo}

Signifikannya Implementasi Kebijakan Diklatpim IV Pola Baru terhadap Kualitas Pelayanan Publik dimediasi oleh Kompetensi Kepemimpinan dengan Pendekatan Mo'odelo ini disebabkan oleh penerapan model $M S N$ Approach dapat diimplementasikan dengan baik, karena ditunjang oleh tingginya tingkat Kompetensi Kepemimpinan dengan Pendekatan Mo'odelo yang terbukti dengan hasil uji pengaruh terhadap kualitas pelayanan publik yang signifikan. Hal ini diperkuat pula oleh hasil wawancara bahwa signifikannya Implementasi Kebijakan Diklatpim IV Pola Baru terhadap Kualitas Pelayanan Publik dimediasi oleh Kompetensi Kepemimpinan dengan Pendekatan Mo'odelo, selain diintervensi oleh implementasi MSNApproach melalui penerapan kurikulum baru yang sesuai kebutuhan peserta, juga diintervensi oleh kompetensi kepemimpinan dengan pendekatan mo'odelo terutama kemampuan berinovasi pejabat eselon IV.

Sementara itu peran mediasi dari kompetensi kepemimpinan dengan pendekatan mo'odelo sebagai katalisator yang memperbesar pengaruh implementasi nilai 
koefisien terbesar yakni dimensi Inovator. Hal ini memberi arti bahwa dimensi inilah berperan menjadi katalisator yang memperbesar pengaruh implementasi kebijakan Diklatpim IV Pola Baru terhadap kualitas pelayanan publik. Peran dari dimensi Inovator terlihat dari peran kepemimpinan pejabat Eselon IV dalam mendorong stafnya dengan ide-ide kreatif melakukan inovasi untuk meningkatkan kualitas pelayanan publik. Peran ini yang disebut oleh Suryanto (2016:7) sebagai Peran Agen Perubahan, yaitu peran pemimpin mendorong proses kreatif bagi aparatur untuk bergerak melakukan terobosan-terobosan guna mencapai kondisi ideal (pelayanan) yang diharapkan.

Pembahasan-pembahasan di atas mengemukakan adanya dua peran penting dari dari masing-masing variabel, yakni peran Implementasi Kebijakan Diklatpim IV Pola Baru dalam meningkatkan kompetensi kepemimpinan dengan pendekatan mo'odelo, dan peran yang kedua adalah peran Kompetensi Kepemimpinan dengan Pendekatan Mo'odelo dalam meningkatkan kualitas pelayanan publik.

\section{Pengembangan Model}

Berdasarkan pembahasan sebelumnya telah diidentifikasi penyebab tidak signifikannya pengaruh implementasi kebijakan Diklatpim IV Pola Baru terhadap kualitas pelayanan publik, yakni kurangnya komitmen dan motivasi dari implementor kebijakan. Begitu juga dengan Kompetensi Kepemimpinan dengan Pendekatan Mo'odelo berpengaruh signifikan terhadap Kualitas Pelayanan Publik disebabkan oleh adanya kemampuan berinovasi pejabat eselon IV di Pemerintah Provinsi Gorontalo. Sehingga dengan demikian ditemukan faktor-faktor penting pengaruh Implementasi Kebijakan Diklatpim IV Pola Baru dan Kompetensi Kepemimpinan dengan Pendekatan Mo'odelo terhadap Kualitas Pelayanan Publik. Faktorfaktor tersebut adalah: (1) Pendekatan MSN (MSN-Approach), (2) Komitmen, (3) Motivasi, dan (4) Kemampuan Berinovasi.

Akan tetapi faktor-faktor tersebut didalam penerapannya tidak dapat dilaksanakan secara parsial tetapi dibutuhkan implementasi secara integral dalam rangka peningkatan Kualitas Pelayanan Publik. Oleh karena itu kerangka model integrasi implementasi faktor-faktor tersebut dapat digambarkan dalam bentuk prototype model yang disebut Prototype Model Integrasi sebagai berikut:

Gambar 1. Prototype Model Integrasi

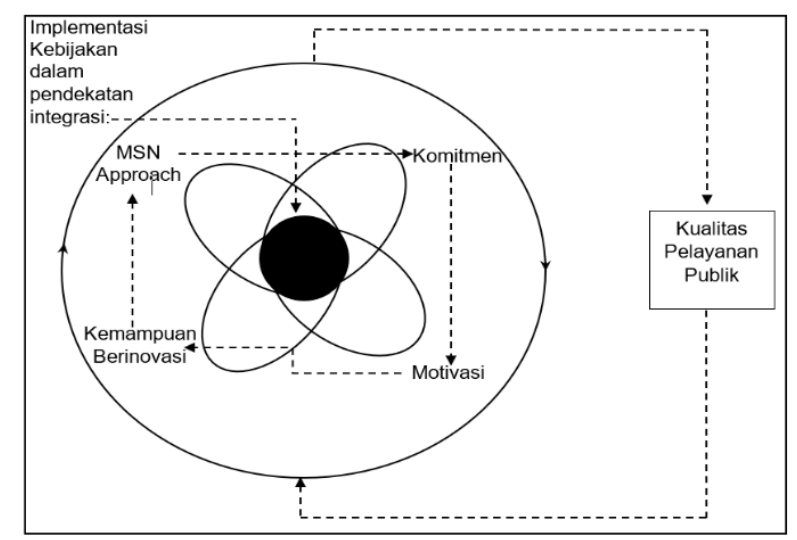


Dalam prototype model ini Komitmen mengandung arti "perjanjian (keterikatan) untuk melakukan sesuatu", yang dihubungkan dengan implementasi kebijakan merupakan tingkat kemauan seorang implementor kebijakan untuk mengimplementasikan kebijakan sesuai dengan besar-kecilnya tingkat perjanjian (keterikatan) dalam diri implementor tersebut. Kegiatan yang dilakukan dalam rangka implementasi kebijakan akan dilaksanakan dengan sebaik-baiknya jika terdapat komitmen yang kuat dalam diri implementor, sebaliknya jika komitmen implementor kurang, maka pelaksanaan kegiatanpun tidak akan berjalan optimal dan hanya sekedar asal jadi. Hal ini menunjukkan bahwa kecenderungan implementor untuk melibatkan diri secara penuh dalam kegiatan implementasi kebijakan bergantung pada seberapa besar komitmennya terhadap tujuan organisasi dimana dia berada. Sopiah (2008:23) menyebut komitmen ini dengan nama lain sebagai komitmen organisasi, yaitu suatu ikatan psikologis pada karyawan yang ditandai dengan adanya Kepercayaan dan penerimaan yang kuat atas tujuan dan nilai-nilai organisasi, kemauan untuk mengusahakan tercapainya kepentingan organsisasi, dan keinginan untuk mempertahankan kedudukan sebagai anggota organisasi. Meyer, Allen and Smith (1993:541) mengemukakan bahwa terdapat tiga aspek komitmen, yaitu: (1) Affective commitment, hal ini berkaitan dengan adanya ikatan emosional karyawan, identifikasi, dan keterlibatan dalam organisasi karena keinginan dari diri sendiri; (2) Continuance commitment, adalah komitmen yang didasarkan akan kebutuhan rasional. Dengan kata lain komitmen ini terbentuk atas dasar untung dan rugi yang didapatkan oleh karyawan.; dan (3) Normative commitment, adalah komitmen yang didasarkan pada norma yang ada dalam diri karyawan. Yang berisi keyakinan individu akan tanggung jawab terhadap organisasi. Berdasarkan tiga aspek komitmen di atas, maka dapat dikemukakan faktor-faktor yang mempengaruhi komitmen seorang implementor kebijakan, yakni: ikatan emosional, kesadaran diri, kebutuhan rasional, norma dan tanggung jawab.

Motivasi dalam prototype model ini di definisikan sebagaimana pendapat Robbins dan Judge (2008:222) sebagai proses yang menjelaskan intensitas, arah, dan ketekunan seorang individu untuk mencapai tujuannya. Intensitas berhubungan dengan seberapa giat seseorang berusaha. Arah berhubungan dengan sesuatu yang menguntungkan organisasi, dan ketekunan merupakan ukuran mengenai berapa lama seseorang bisa bertahan dalam berusaha. Dalam proses implementasi kebijakan, ketiga aspek ini mempengaruhi implementor kebijakan dalam mendorong semangat dan perilakunya untuk melaksanakan tugas guna pencapaian tujuan implementasi kebijakan tersebut. 
Sedangkan Kemampuan berinovasi dalam prototype model ini, adalah karakteristik dari kepemimpinan "Mo'odelo" sebagaimana dikemukakan oleh Botutihe (2006:130) merupakan intisari dari delapan prasyarat kepemimpinan mo'odelo di Gorontalo adalah “mopotuwawu kalibi, pi'ili wawu qauli” atau adanya keserasian (integritas) antara kalbu (hati nurani), perilaku dan perkataan, serta kemampuan berpikir dan manajerial yang kuat. Karakteristik ini melahirkan dorongan yang kuat untuk memikirkan ide-ide maupun gagasan baru yang lebih inovatif guna merespons tuntutan kebutuhan akan pelayanan yang lebih baik dari masyarakat yang dilayani. Hal ini sejalan dengan pendapat Christopher and Thor (2001:65) bahwa inovasi muncul karena adanya dorongan dari dalam (internal) untuk melakukan perubahan, dan karena adanya desakan kebutuhan dari pihak luar (eksternal) misalnya permintaan konsumen. Kemampuan berinovasi ini menurut De Jong (2007:26-28) meliputi: (1) Opportunity exploration, proses inovasi ditentukan oleh kesempatan yang memicu individu untuk mencari atau memikirkan sebuah alternatif baru mengenai proses kerja, produk atau pelayanan. (2) Idea generation, membangkitkan sebuah konsep untuk peningkatan performansi. (3) Championing, melibatkan perilaku untuk mencari dukungan dan membangun koalisi, seperti mengajak dan mempengaruhi karyawan atau manajemen, dan bernegoisasi mengenai suatu solusi. (4) Application, individu tidak hanya memikirkan ide-ide kreatif terhadap suatu hal tapi juga mengaplikasikan ide tersebut ke dalam tindakan nyata.

\section{KESIMPULAN DAN SARAN}

Berdasarkan hasil penelitian dan pembahasan maka dapat disimpulkan hal-hal sebagai berikut:

1. Tidak terdapat pengaruh langsung secara signifikan Implementasi Kebijakan Diklatpim IV Pola Baru terhadap Kualitas Pelayanan Publik di Pemerintah Provinsi Gorontalo.

2. Terdapat pengaruh signifikan Implementasi Kebijakan Diklatpim IV Pola Baru terhadap Kompetensi Kepemimpinan dengan pendekatan mo'odelo di Pemerintah Provinsi Gorontalo.

3. Terdapat pengaruh signifikan Kompetensi Kepemimpinan dengan pendekatan mo'odelo terhadap Kualitas Pelayanan Publik di Pemerintah Provinsi Gorontalo.

4. Terdapat pengaruh tidak langsung secara signifikan Implementasi Kebijakan Diklatpim IV Pola Baru terhadap Kualitas Pelayanan Publik di mediasi oleh Kompetensi Kepemimpinan mo'odelo.

5. Pengembangan model implementasi kebijakan Diklatpim IV Pola Baru dan kompetensi kepemimpinan Mo'odelo untuk peningkatan kualitas pelayanan 
publik menghasilkan suatu prototype model implementasi kebijakan terintegrasi dengan temuan penelitian yakni: komitmen, motivasi, dan kemampuan berinovasi.

Berdasarkan simpulan di atas, maka dapat diajukan saran-saran sebagai berikut:

1. Disarankan kepada Badan Diklat Provinsi Gorontalo meningkatkan komitmen dan motivasi para implementor kebijakan Diklatpim IV Pola Baru melalui kegiatan membangun komitmen bersama dan meningkatkan motivasi implementor melalui pemberian tambahan penghasilan atas kelebihan Jam Pembelajaran.

2. Disarankan kepada Pemerintah Provinsi Gorontalo agar melakukan program pengembangan Kompetensi Kepemimpinan Mo'odelo kepada pejabatpejabat strukturalnya.

3. Untuk mengetahui efektifitas Prototype Model Integrasi dalam implementasi kebijakan, maka disarankan kepada peneliti selanjutnya untuk melakukan penelitian lanjutan dalam rangka pengujian efektifitas model ini.

\section{REFERENSI}

Astra, Fadilla. Mandey, Jantje, dan Londa, Very. 2016. Pengaruh Pendidikan dan Pelatihan Struktural terhadap Kompetensi Kepemimpinan Aparatur Sipil Negara: Studi di Sekretariat Daerah Kota Bitung. Jurnal Administrasi Publik Universitas Sam Ratulangi Vol.3 No.400 tahun 2016.
Basir, M. Askal. 2016. Pengaruh Pendidikan dan Pelatihan, Motivasi Kerja Terhadap Kualitas Pelayanan Dinas Kependudukan dan Catatan Sipil Kota Baubau. Jurnal Ilmu Pemerintahan Universitas Muhammadiyah Buton Vol.1 No.1 April 2016.

Botutihe, Medi. 2006. Mo'odelo: Sifat dan Perilaku Pemimpin Berdasarkan Nilai Lokal Gorontalo. Gorontalo: Pustaka Gorontalo.

Botutihe, Medi. dan Daulima, Farha. 2005. Pedoman Tata Upacara Adat Gorontalo. Jakarta: Media Otda

Christopher, William F., and Thor, Carl G. 2001. World-Class Quality and Productivity: Fiveteen Strategies for Improving Performance. United Kingdom: Financial World Publishing.

De Jong, Jeroen. 2007. Individual Innovation: The Connection between Leadership and Employees. Netherlands: EIM Business and Policy Research.

Edward III, George, 1980, Implementing Public Policy. Washingthon DC: Congressional Quarterly Press.

Ghozali, I., Latan, H. 2015. Konsep, Teknik, Aplikasi Menggunakan Smart PLS 3.0 Untuk Penelitian Empiris. Semarang: BP Undip.

Hasibuan, Malayu S.P. 2003. Manajemen Sumber Daya Manusia, Edisi Revisi, Jakarta: Bumi Aksara.

Heifetz, Ronald. Grashow, Alexander., and Linsky, Marty. 2009. The Practice of Adaptive Leadership. Massachusetts. UK: Harvard Business Press

Ibrahim, Irfan, 2018. Implementasi Kebijakan Diklatpim IV Pola Baru Dalam Meningkatkan Kualitas Pelayanan Publik di Pemerintah Provinsi Gorontalo. Jurnal Ilmu Administrasi STIA LAN Bandung 
Volume XV Nomor 2 Desember 2018. p 242-260.

Ibrahim, Irfan,, 2018. Pengaruh Implementasi Kebijakan Pendidikan dan Pelatihan Kepemimpinan Tingkat IV Pola Baru Terhadap Kompetensi Kepemimpinan Pejabat Pengawas di Lingkungan Pemerintah Provinsi Gorontalo. Jurnal Ilmiah Ilmu Administrasi Publik UNM Makassar Volume 8 Nomor 2 JuliDesember 2018. p 165-172.

Kadji, Yulianto. 2015. Formulasi Dan Implementasi Kebijakan Publik. Gorontalo: UNG Press.

Kadji, Yulianto, 2016. Metode Penelitian Ilmu Administrasi. Yogyakarta: Deepublish.

Meyer, J.P, Allen, N.J. \& Smith, C.A. 1993. Commitment to Organizations and Occupations: Extension and Test of A Three Component Conceptualization. Journal of Applied Psychology, 78 (4), 538-551.

Muhadi. 2017. Pengaruh Tingkat Pendidikan, Pelatihan dan Pengalaman Kerja Terhadap Peningkatan Kinerja Pelayanan Kepala Urusan (KAUR) di Desa (Studi pada Desa se Kecamatan Natar Kabupaten Lampung Selatan). Tesis. Universitas Lampung. Bandar Lampung.

Mulyadi, Mohammad. 2016. Metode Penelitian Praktis, Kuantitatif dan Kualitatif. Jakarta: Publica Press.

Parasuraman, A., Zeithaml, V.A. and Berry, L.L.1988. SERVQUAL: A Multi-Item Scale For Measuring Consumer Perceptions of The Service Quality. Journal of Retailing, Vol. 64, No. 1, pp. 12-40.

Pranata, Fajar Irja. 2015. Pengaruh Kompetensi Aparatur Pemerintah Terhadap Kualitas Pelayanan Publik Pada Kantor Kecamatan Sangatta Selatan Kabupaten
Kutai Timur. Jurnal Ilmu Sosial Untag 1945 Samarinda Vol.1 No.2 Tahun 2015.

Punu, A. Sintia., Rompas, W.Y., dan Tampongangoy, Deysi L. 2014. Pengaruh Pendidikan dan Pelatihan (Diklat) Terhadap Kompetensi Kerja Aparatur di Sekretariat Daerah Kota Tomohon. Jurnal Administrasi Publik Universitas Sam Ratulangi Manado Vol. 3 No. 004 Tahun 2014.

Robbins, Stephen P. 2002. Prinsip-prinsip Perilaku Organisasi. Terjemahan: Halida.Edisi Kelima. Jakarta: Erlangga.

Robbins, Stephen, P. and Judge, A. Timothy. 2008. Perilaku Organisasi. Buku 1. Edisi ke-12. Jakarta: Salemba Empat.

Rondinelli, Dennis. 1998. Privatization, Governance, and Public Management: The Challenges Ahead. Business and The Contemporary World Vol.10 No.2 1998, p.167

Setiawan, dkk. 2015. Pengaruh Kepemimpinan Pelayan Terhadap Kinerja Pelayanan Publik Pegawai Negeri Sipil pada Pemerintah Kota Bekasi. Proceeding Seminar Psikologi dan Kemanusiaan. Malang: Psychology Forum UMM,

Setyawan, Dodi., dan Bagus, Nanang. 2014. Kualitas Kepemimpinan, Etos Moralitas Pribadi, Kompetensi, dan Pelayanan Publik. Jurnal Ilmu Administrasi Negara UTT Malang Vol.13 No. 1, Juli 2014.

Sopiah. 2008. Perilaku Organisasi. Yogyakarta: Andi.

Suryanto, Adi. 2016. Sistem Pengembangan Kader Pimpinan ASN: Sebuah Strategi Resolusi Percepatan Reformasi Birokrasi di Indonesia. Jurnal Pendayagunaan Aparatur Negara Vol.VI Tahun 2016.

Syukur, M. Hasan. 2015. Diklat Kepemimpinan Pola Baru, Apa, Bagaimana Implementasinya dan 
Tantangannya. Jurnal Forum Diklat Vol.04 No.2 Tahun 2015

Wahab, A Solichin. 2016. Analisis Kebijakan: Dari Formulasi Ke Penyusunan ModelModel Implementasi Kebijakan Publik. Jakarta: Bumi Aksara.
Weimer, David, L. and Vining, Aidan. R.1999. Policy Analysis: Concepts and Practice. New Jersey: Prentice Hall, Third Edition.

Widodo, Joko.2002. Akuntabilitas dan Kontrol Birokrasi. Surabaya:Insan Cendekia

Worsfold, Philip. 1999. HRM, Performance Index Approach to Managing. Service Quality, Vol.10, No.5, p.273-278. 